\title{
On comparative study of deverbal nominalizations denoting process and result in Lithuanian and English
}

\section{Lietuviešu un angḷ valodas verbālo nominalizāciju sastatāmā analize}

\author{
Solveiga Sušinskienė, Jolanta Vaskelienė \\ Institute of Regional Development \\ Šiauliai University \\ Višinskio St. 38, LT-76352 Šiauliai, Lithuania \\ E-mail: solveiga.susinskiene@su.lt, jolanta.vaskeliene@su.lt
}

\begin{abstract}
Although the Lithuanian and English languages are bound within the family of IndoEuropean languages, the typological differences between the two languages lie in the system of inflectional and derivational morphology. The paper analyses the concept of nominalization and discusses the deverbal process and result nominalizations in Lithuanian and English. For the comparative qualitative and quantitative analysis, 965 equivalents of deverbal nouns have been selected from the "Parallel Corpus". Out of them, 802 examples belong to the category of deverbal process nouns, whilst the category of deverbal result nouns includes 163 examples.

From the point of view of morphology, in both languages nominalization is a word-formation process by which a noun is derived from a verb, adjective or another noun, or even other parts of speech, usually through suffixation and by adding the ending in the Lithuanian language. Two types of nominalization can be found across languages: lexical and syntactic. Lexical nominalization refers to the formation of deverbal nouns or nominal words derived from the verb or a nominal word, and syntactic nominalization refers to turning a clause into a noun phrase.

In summary, the investigation of the derivational affixes of deverbal nouns in Lithuanian and their equivalents in English has revealed the following differences: in Lithuanian, the deverbal nominalizations - deverbal process nouns and deverbal result nouns - can be formed with 132 suffixes and 5 endings, whilst in English - with 10 suffixes and by employing the derivational strategy of conversion. Also, the analysis of the empirical material revealed that the suffix -imas/-ymas in Lithuanian prevails in forming deverbal process nouns (they make 73 per cent of all deverbal process nouns), while the suffix -inys is the most prolific in forming deverbal result nouns (they make 38 per cent of all deverbal result nouns). The English equivalents usually have the suffix -ion/-tion/-sion/-ation, quite many derivatives have the suffix -ing. It should be noted that deverbal nominalizations in the Lithuanian language often correlate with abstract and concrete nouns (non-derivatives) in the English language: 23 per cent of all derivatives in Lithuanian have more than one equivalent (derivative or non-derivative) in English.
\end{abstract}

Keywords: nominalization; suffix; ending; deverbal nouns; derivative; Lithuanian; English. 


\section{Introductory observations on nominalization}

Language is a flexible system. Its flexibility manifests itself in the ability of its units to adapt to changing needs by making the units assume new functions. In assuming "new duties" language units - words - undergo appropriate modifications. The phenomenon of nominalization is an area which has attracted the interest of a vast number of researchers (Comrie 1976, 177-201; Koptjevskaja-Tamm 2003, 723-759; Andersen 2007, 55-86; Kiparsky 2017, 311-346; Veselovska 2018, 1-21 among others) due to the reason that the data on a number of languages have become available. The phenomenon of nominalization has been analysed from the point of view of morphology, syntax, semantics, and text linguistics in crosslanguage studies.

Morphologically speaking, nominalization is a word-formation process by which nouns are derived from verbs, adjectives, other nouns, or even other parts of speech, usually through suffixation. To quote the popular definition proposed by Quirk, "Semantically nominalizations are thus usually related to a verb, such as involvement to involve, but they can also be related to an adjective, such as darkness to dark. They are usually nominal phrases derived from clauses" (Quirk et al. 1985, 1288). Comrie and Thompson $(1985,334)$ define nominalization as the process of "turning something into a noun". Also, nominalization can be defined as the process by which a non-nominal element is made to function as a nominal element (see Sušinskienè 2010, 58-63). Therefore, deverbal nominalizations provide vast space for research because of their complex morphological, lexical, and syntactic nature.

Nominalization as a subject of linguistic research has been studied widely over the last fifty years from different theoretical approaches. Each approach raises different questions of the data and gives results employing divergent classifications, generalizations, and argumentation. Therefore, nominalization presents a theoretical challenge and must be fixed in a general theory of the language system. With the appearance of a new variety of structuralism - transformationalgenerative-grammar - the study of nominalizations gave way to studies that were concerned with the further elaboration of Chomsky's generative mechanism. A transformational analysis of nominalizations continued to attract the attention of linguists despite the new approach to which nominalizations were treated as part of the deep structure of the sentence. The earliest generative studies derived all nominalizations syntactically (Chomsky 1970). Chomsky $(1970,184)$ argued that only -ing gerunds are derived syntactically, while all other types of event nominals, such as arrival, acceptance, departure, are derived morphologically in the lexicon from bases that are unspecified between nouns and verbs. The suffix -ing was shown to serve both as the gerund formative and as one of the formatives that derive lexical event nominals. Chomsky's (ibid.) key argument was related to the idea that only gerundive phrases have the structure of verb phrases, whereas other event nominals have the structure of noun phrases.

However, Chomskian generative grammar seemed to many not to pay enough attention to language-specific morphology. Interest in morphology has increased since the late 1970s and early 1980s when more languages became the subject matter of generative analyses (Veselovska 2018, 1-21). Furthermore, 
transformational-generative grammarians came to understand that the Chomskian deep structure was not deep enough. The leading proponents of the new version of transformational-generative grammar were such noted linguists as McCawley (1968, 125-169), Fillmore (1969, 361-375), and Lakoff (1970). One would expect that the new theory, which postulates that semantic structure is a set of relationships of the verb with the noun, worked as a new stimulus to a transformational description of nominalizations: it allowed generating both predicative and nonpredicative structures from the same deep (semantic) structure. Unfortunately, the time of transformational grammar had already passed, and linguists now focused their attention on the semantics of the sentence rather than on the transformational relationship between linguistic structures.

A new impetus to the study of nominalizations was given in the 1980 s by the work of functional grammarians. Functional linguists produced two markedly different directions in the study of nominalizations: one, more theoretical, represented by Jackendoff (1981), Givón (1984), Mackenzie (1998) who focused their analysis on the study of nominalizing transformations, the other, a less 'formalist' direction, which leads towards Halliday's general theory of the phenomenon of nominalization, referred by him to as grammatical metaphor. To Halliday $(1985,321)$, a nominalization is the result of the metaphorization of the Process. Nominalization, then, is a linguistic mechanism, whereby the Process is realized as an Entity. According to Halliday's theory (ibid.), a nominalization is not an autonomous unit; it arises in the text and is based on an underlying proposition which is a set of the relationships of the verb and its actants.

Ravelli $(1988,141)$ proposes two devices that can be used in the analysis of the metaphorical realization of processes as deverbal nouns: derivation and agnation. Derivation is the major tool of turning processes into participants denoted by deverbal nouns. She uses the term 'agnation' to denote the relation between a nominalized structure and its non-nominal counterpart (e. g. his death - he died). The use of agnation in the metaphorical analysis of nominalizations allows us to fully understand the meaning of the metaphorical expression of the process by comparing it to the agnate form corresponding to its congruent realization. As indicated by Heyvaert $(2003,70)$, each verb-based nominalization can be related to one congruent agnate.

Banks $(2003,129)$ argues that there are a number of options creating nominalized forms of processes, though not all options are necessarily available for an individual verb: 1) nominalizations which are morphologically identical with agnate (i. e. base) verb (e.g. haul, estimate, change); 2) nominalizations which have no agnate verb, but which nevertheless indicate a process (e.g. trend, occasion, war); 3) nominalizations which have an agnate verb, but are not morphologically identical (e. g. growth, preference, reading).

Comrie and Thompson $(1985,334)$ indicate that two types of nominalization can be found across languages: lexical and clausal. Lexical nominalization refers to the creation of lexical nouns (deverbal nouns) from verbs or adjectives and the clausal (syntactic) nominalization refers to turning a clause into a noun phrase. For example, in lexical nominalization to arrive - arrival, the derived noun results from lexical nominalization, and the noun phrase John's arrival is a product of 
syntactic nominalization (John arrived - John's arrival). Furthermore, lexical nominalization is a process that derives an abstract or concrete noun from another lexical category (verb, adjective, or another noun) through a morphological process. Consider the following examples:

(1) to communicate - communication, legal - legalization, child - childhood;

(2) eiti 'to go' - ejimas 'going', gražus 'beautiful' - grožis 'beauty', pušis 'pine' pušynas 'pinewood'.

In Lithuanian linguistics, the term 'nominalization' is not widely used, e. g. in Kalbotyros terminu žodynas (Gaivenis, Keinys 1990), it is not indicated, in Lietuviu kalbos enciklopedija (Ambrazas 2008, 375), nominalization is defined as the transformation of a verbal word combination or the whole sentence to a nominal word combination, when a verb is replaced by a corresponding deverbal noun (e.g. I Vilniu atvyko Romos pasiuntiniai (Roman envoys arrived in Vilnius) $\rightarrow$ Romos pasiuntiniu atvykimas $i$ Vilniu visus nustebino (The arrival of Roman envoys in Vilnius surprised everyone)), thus emphasizing the syntactic aspect. Also, nominalization may be defined as the formation of deverbal nouns and the replacement of corresponding verbal combinations (or entire sentences) with nominal word combinations (see Tumelis et al. 2009, 484). It should be noted that in the Lithuanian language the deverbal nouns derived with the suffix -imas/-ymas are quite frequent, and the nominative of the subject of verbal combinations and the accusative of the direct object are changed into genitive phrases (cf. Kolumbas atrado Amerika (Columbus discovered America) $\rightarrow$ Kolumbo Amerikos atradimas (Columbus' discovery of America). Also, the transformation of the adjective into the noun is a type of nominalization (bright $\rightarrow$ brightness, šviesus $\rightarrow$ šviesumas) (for more information see Ambrazas 1997, 560-561, 569; Pakerys 2006; Zaika 2016).

The present paper focuses on the derivation of deverbal nominalizations denoting process and result in Lithuanian and English. The research based on the data presented below will demonstrate that morphological processes are involved in the derivation of Lithuanian and English deverbal nouns that are primarily coined by a morphological process of suffixation (in the English language) and by a morphological process of suffixation and inflection (i.e. by the addition of endings to the verb stems) in the Lithuanian language. Deverbal nouns are often referred to as hybrids, containing both verbal and nominal features.

The rest of the paper is structured as follows: Section 2 provides a brief typological description of deverbal nominalizations in Lithuanian; Section 3 views the derivational aspects of deverbal nominalizations in English; Section 4 describes the affixation of deverbal process and result nominalizations in both languages; Section 5 concludes the paper.

\section{The derivation of deverbal nominalizations denoting process and result in Lithuanian}

In the Lithuanian language, the derivative is a word that is derived from another word or two other words. "Genetically, the derivative is the word that occurs due to word derivation, whilst functionally it is the word which is perceived 
as the result of word derivation" (Urbutis 2009, 73) (cf. Gaivenis, Keinys 1990, 43; Keinys 1999, 107; Ambrazas 2008, 130-131).

In Lithuanian, there are four main ways of word derivation: suffixation, prefixation, paradigmation, and composition. Also, there are cases of mixed type derivation, when two types of derivation occur at the same time: prefixation and suffixation, composition, and suffixation. The mixed type of word derivation is more characteristic to adjectives and adverbs (Keinys 1999, 22-23, 82-83, 102; Ambrazas 2008,121; Urbutis 2009, 333-342). Word formations that are based on one underlying word are called derivatives (hence there are derivatives with suffixes, derivatives with prefixes, and derivatives with endings), and word formations that are based on two underlying words are called compound words (a separate issue of word derivation consists of a specific phenomenon - the socalled backward or retrograde derivation (buvèlis, $-\dot{e}:$ nebuvelis, $-\dot{e}$ ) (see Keinys 1999, 23; Urbutis 2009, 342-346).

The nouns in the Lithuanian language are formed by using all four main types of derivation. Derivatives with suffixes and derivatives with endings that have many similarities, according to the identity of the two differential features (i. e. generalized derivational meaning and the part of speech of the underlying word (or several parts of speech)), are divided into derivation categories or derivation classes (see Ulvydas 1965, 253-423, Keinys 1999, Ambrazas 2005, 86-145). Nouns are formed from various parts of speech: nouns, adjectives, verbs, sometimes from pronouns, numerals, and adverbs. The deverbal process nouns, nouns denoting persons, nouns denoting objects or results of action, nouns denoting instruments and devices, nouns denoting places, festivals or ceremonies may be derived from verbs (Paulauskiené, Valeika 1994, 349-353).

In the Lithuanian language, deverbal process nouns can be formed with 71 suffixes and 5 endings, deverbal process nouns of standard Lithuanian language are formed with 47 suffixes (other suffixes are quite rare, they are usually used in dialects, there are four suffixes used to form international words) (Ulvydas 1965, 289-303; Keinys 1999, 39-41, 57). Ambrazas, the researcher of diachronic word formation, indicates more than 110 suffixes and 6 endings of deverbal process nouns (Ambrazas 1993, 20). The most productive suffix of this derivational category is -imas/-ymas - it can be used to derive nouns from any verb (although in the Lithuanian grammars this suffix is designated as two separate types of derivation, i. e. -imas and -ymas, they both are considered to be as the allomorphs of the same suffix (Gaivenis, Keinys 1990, 225; Paulauskiené 1994, 75-76; Paulauskienè, Valeika 1994, 349-350). Other productive suffixes are -tis, -esys, -ulys, -yba (-ybos), -smas, -sena, -tynés, etc., endings -a, -is (-ys) (see Ambrazas 2005, 94-100). For example:

(3) elgimasis 'treatment', ejjimas 'going', nešimas 'carrying'; mokymas 'teaching', rašymas 'writing', skaitymas 'reading'; apsuptis 'ambience', išpažintis 'confession', užduotis 'task'; barškesys 'rattle', šnaresys 'swish', üžesys 'noise'; čiaudulys 'sneeze', dusulys 'choke', kosulys 'cough'; daugyba 'multiplication', statyba 'building', tapyba 'painting'; džiaugsmas 'joy', šauksmas 'cry', veiksmas 'action'; būsena 'state', mąstysena 
'mindset', rašysena 'handwriting'; imtynès 'wrestle', kautynès 'battle',

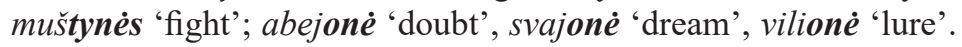

There are suffixes of international words (-acija, -ija):

(4) agitacija 'agitation', asimiliacija 'assimilation', interpretacija 'interpretation'; amnestija 'amnesty', aneksija 'annexation', garantija 'guarantee'.

Also, there are the endings that form nominalizations in the Lithuanian language:

(5) ištuoka 'divorce', nuojauta 'flair', pajuoka 'mock', kančia 'pain'; ìtūžis 'fury', spyris 'kick', atlydys 'thaw'; juokas 'laugh', skundas 'complaint', atsakas 'reply'; pergale 'victory', išmone 'artifice'; stygius 'lack', gyrius 'praise', etc.

Deverbal process nouns indicate not objects but processes and states. They are transpositional derivatives (Urbutis 2009, 195-199), however, some of them fully retain their categorical meaning, others acquire additional semantic components, or they may indicate the result of the process. For instance:

(6) audimas 'weaving' (process) - audimas 'texture' (cloth, fabric); vertimas 'translation' (process) - vertimas 'a translation' (a text translated from one language to another); išejimas 'departure' (process) - išejimas 'exit' (space to leave the place); skaitymas 'reading' (process) - skaitymas 'a reader' (a text for reading).

The derivation and semantics of deverbal nouns were analysed by Ambrazas (1993, 20-85), Murmulaityte (1997), the issues of synonymity of conjugate derivatives were analysed by Vaskelienè (1998).

The deverbal result nouns indicate the results and objects. They may be derived with 61 suffixes and 5 endings (see Ulvydas 1965, 368-381). Keinys (1999, 43, 58-59) indicates 40 suffixes and 5 endings of the standard Lithuanian language. However, from a diachronic point of view, there used to be more derivational affixes: Ambrazas $(1993,86)$ indicates 80 suffixes and 6 endings. The deverbal result nouns formed with suffixes are:

(7) kepinys 'a pastry', pirkinys 'a purchase', sviedinys 'a ball'; geralas 'a drink', tirpalas 'a leach', viralas 'a pottage'; demuo 'a component', rašmuo 'a graphic'; iškasena 'an excavation', lupena 'a peel'; nuodègulys 'a firebrand', rišulys 'a bundle'; nuostolis 'a damage', priedèlis 'an appendage'; džiūvèsis 'a hardtack', pelèsis 'a mould'; raštas 'a script', pluoštas 'a fibre', žlugtas 'a wash'; falsifikatas 'a falsification', preparatas 'a preparation', etc.

The derivatives with endings that belong to this category are:

atplaiša 'a splinter', sandauga 'a product'; illūǔis 'a break', nuosprendis 'a judgement', plyšys 'a crack'; iddaras 'a filling', ispaudas 'a stamp', pastatas 'a building', užrašas 'an inscription'; rieke 'a slice', pramoné 'an industry'; lykius 'a remainder', skyrius 'a chapter'.

In summary, it can be stated that in the Lithuanian language deverbal nouns make a big part of nominal derivatives. The analysed deverbal process nouns and deverbal result nouns are similar in both the form and meaning, they are usually formed with the same affixes (Ambrazas 1993, 86). Deverbal process nouns stand 
out in the abundance of their derivatives. In this category of derivation, the type of the suffix -imas/-ymas is the most prolific, as with the suffix -imas/-ymas the derivative may be formed from any verb. Moreover, in both categories (i. e. deverbal process nouns and deverbal result nouns), some verbs may be used to form derivatives with more than one affix, therefore, there are more derivatives than the verbs themselves.

\section{The derivation of deverbal nominalizations denoting process and result in English}

The English language cannot boast of inflectional morphology, but there is a large inventory of word-formation devices (compounding, prefixation, suffixation, conversion, blending, and clipping). Employing suffixation, nominalizations in English can be formed from adjectives, verbs, and other nouns. Consider, respectively:

(9) able-ability, careful-carefulness, prosperous - prosperity, kind-kindness; to speak - speaking, to communicate - communication, to estimate estimation; child - childhood, king - kingdom, neighbour - neighbourhood.

There are two types of the derivation of deverbal nominalizations (deverbal nouns):

1) by adding a suffix;

2) through conversion (zero derivation).

The group of nominalizations derived from the verb may be so-called gerundive nominalizations, which are formed from verbs by adding the -ing suffix (to write - writing). Also, nominalizations can be derived with socalled Latinate suffixes: -age (to use - usage), -al (to arrive - arrival), -ance/-ence (to accept - acceptance), -(e)ry (to discover - discovery), -ion/-sion/-tion/-ation (to communicate - communication), -ment (to develop development), -ure (to close - closure), -th (to die - death).

Referring to Marchand (1969, 209-215), a suffixal derivative is primarily a lexical form. It is a two- morpheme word that behaves like a one-morpheme word. Derivation considered as the process of moving a word into another wordclass varies in aspect, according to whether we transpose a noun into a verb or a verb into a noun. The difference relates to the difference of word classes themselves. The linguist proposes that a verb is a complete utterance, while a noun is only part of an utterance. A suffix has no meaning, it acquires meaning only in conjunction with the free morpheme which it transposes. A suffix does not name the semantic class but merely implies it. Some suffixes (e. g. -er, -or, -ee, -ist) have a large combinatory range, while others are restricted in this respect (e. g. -al, -ure, -ery). Basically, in English, a suffix is a categorizer whose function is to transpose a word into another word class.

The second group of nominalizations is derived through conversion (e.g. to use - a use, to answer - an answer, to call - a call, etc.). During the process of conversion, an item changes its category without the addition of a suffix. As noted by Adams $(1973,14)$, "The majority of suffixes in English are class-changing, and so form words which behave syntactically very different from their bases". When 
a word which has hitherto functioned as a member of one class undergoes a shift which enables it to function as a member of another, we have what is traditionally called 'conversion'. It is the word-formation process when "an item is adapted or converted to a new word-class without the addition of an affix" (Quirk et al.1985, 1009).

Furthermore, it is possible to divide deverbal nominalizations into semantic categories: deverbal abstract nouns, deverbal result nouns, deverbal agentive nouns, deverbal instrumental nouns, and deverbal locative nouns. According to Plag (2016, 2417), all event nominalizations can be divided into results (acceptance, compression), products (drawing, sculpture), instruments (trimming, refreshment), locations (enclosure, residence), agents (administration, government), measure terms (abundance), paths (ascendance, continuation), patients (payment, substitution), and states (annoyance, boredom).

Verbs from which the deverbal nominalizations are derived can be divided into two categories: inherently imperfective (durative) and inherently perfective (nondurative). Therefore, depending on their lexical properties, and at the same time on the suffixes added to the stem, English verbs have corresponding nominalizations (i. e. deverbal process nouns and deverbal result nouns). Inherently imperfective verbs are unbounded, i.e. they denote the processes that have no built-in end, e. g. John is paying the piano, where the process expressed by the verb play is unbounded. An imperfective process is a process that is continuing, i. e. a process that has been started but has not reached its end, e.g. John is working now. A perfective process is the opposite of a durative process: it is a process that has passed through all the three phases: inceptive (beginning), medial (middle), and terminal (end). The inceptive phase generally takes a very short time to end (The child is beginning to draw a house); the medial phase takes a relatively long time to end, i. e. a concluding point (The child is drawing a house); and the terminal phase is, in fact, a point (The child has drawn a house) (see Valeika, Sušinskienè 2012, 7-8).

Deverbal process nouns and deverbal result nouns are derived from the verbs inherent with imperfective and perfective verbal aspects, respectively. Deverbal process nouns are derived through the suffixes and conversion. Consider:

(10) -age, e.g. usage, leakage; -ery/-ary/-ry, e. g. mockery, cajolery, debauchery, drudgery, flattery; -ment, e.g. development, improvement, movement; -al, e.g. perusal, portrayal; -ance/-ence, e.g. dominance, existence, abhorrence; -ion/-sion/-tion/-ation, e. g. communication, investigation, imagination; -ing, e.g. understanding, speaking, feeling; -ure, e.g. pressure; -th, e. g. growth; zero derivation (conversion), e.g. demand, dispute, rise, decline, study, exhibit, deposit, etc.

The category of deverbal result nouns indicates the result or product of the action. They can be derived through the same suffixes as well as through conversion. For instance:

(11) -age, e.g. stoppage, shrinkage, blockage; -ery/-ary/-ry, e.g. discovery, delivery, commentary, injury; -ment, e. g. appointment, judgement, statement; -al, e. g. arrival, removal, proposal, survival; -ing, e. g. a writing, a warning, a ruling (legal decision); -ance/-ence, e. g. acceptance, admittance; -ion/-sion/ 
-tion/-ation, e.g. combination, publication, collection; -ure, e.g. departure, failure, closure; -th, e.g. death; zero derivation (conversion), e.g. advise, aid, answer, collapse, etc.

It should be noted, that in English deverbal nouns can express the meaning ranging from a process through an abstract result to the concrete result, usually this is determined by their co-text (i. e. linguistic environment), e. g.:

(12) writing (the activity of writing) - writing (the particular way that someone writes) - a writing (a book, poem, article, etc.); embroidery (the activity of sewing patterns onto cloth) - an embroidery (a pattern sewn onto cloth).

Moreover, deverbal nouns do not form a homogeneous class, they may be ambiguous as well. Consider two examples:

(13) a. The examination took three hours,

b. The examinations were on the table.

As the examples above illustrate, deverbal nouns, such as examination and examinations, are ambiguous between a process reading and a result reading.

To sum up, in the English language, deverbal nouns obtained through transpositional suffixes (such as -al, -ment, -ure, etc.) are commonly known as nouns of action (nomina actionis) or nominalizations, i. e. nouns which denote the process described by the corresponding verbs. Deverbal nouns in English allow at least two distinct semantic interpretations: the process and the result. Deverbal process nouns become result nouns (countable nouns) when they represent an instance of the abstract concept. To put in other terms, deverbal result nouns can be entities that come into existence during the process denoted by the base verb, i. e. result nouns refer to entities either concrete or abstract. Being highly sensitive to aspect, deverbal nouns are also known for a specific lexical ambiguity phenomenon: they may denote the process (action) or the result of the process (action) of the corresponding verbs.

\section{The affixation of deverbal process and result nominalizations in Lithuanian and English}

\subsection{Methodological considerations}

Although the Lithuanian and English languages are bound within the family of Indo-European languages, the typological differences between the two languages lie in the system of inflectional and derivational morphology. The typological differences between Lithuanian and English are especially significant at the morphological level.

Both the qualitative and quantitative methods were applied in the present research. To reveal the typology of both languages, the direction of the analysis is from Lithuanian to English. The research was conducted within the framework of the contrastive method, which allowed us to compare the texts of both languages. Therefore, the research is based on empirical evidence obtained from the comparison of the suffixes (and endings) added to a verb stem in Lithuanian and English. In English, the number of suffixes forming the deverbal nouns denoting process and result is not so prolific in comparison to the inventory of suffixes and endings 
in Lithuanian. Firstly, Lithuanian (a synthetic language) has a far larger number of nouns and verbs derived, respectively, by substantival and verbal suffixes, and secondly, the inflection systems of nouns and verbs are also distinctly different and more prolific in comparison to English (an analytic language). However, being a predominantly analytic language, English has developed adequate compensatory devices. What in the English language is expressed through prepositions, particles, auxiliary verbs in the Lithuanian language is inflected with prefixes, suffixes, or inner inflection (e.g. at weekend - savaitgali, sit down - atsisésti, jis atvyko he has arrived, etc.). Furthermore, in Lithuanian, the endings themselves indicate whether the word is a noun or a verb. In English, nouns and verbs are rarely derived by distinctly substantival or verbal suffixes. This process, however, involves derivational changes (the attachment of suffixes and prefixes), whereas English often allows the transition from one category into another without any such derivational changes, i. e. the so-called conversion, which is strongly characteristic of English (e.g. to use - a use, to question - a question, to answer - an answer, to cut - a cut, etc.).

Also, the method of descriptive analysis was employed in the present study. A descriptive method was used to describe the particularities of all above mentioned deverbal nominalizations of the Lithuanian and English languages separately, invoking grammatical (word formation) rules, principles, and data.

As translation studies are supplementary to contrastive analysis, for the empirical research we have chosen the examples from Lygiagretusis tekstynas (Parallel Corpus), available at https://klc.vdu.lt/en/parallel-corpus/. The purpose of translation is to convey the intended meaning from a source text to a target text, thus, in our case, we have chosen Lithuanian as a source text and English as a target text. As the equivalence of lexical systems of the compared languages is determined by translation criteria, the translation equivalents (i. e. deverbal nominalizations) are researched at the level of contrasting language systems.

The quantitative method was used to reveal the incidence of the features of the deverbal nominalizations examined. For the comparative quantitative analysis, 965 examples (interlingual equivalents) with deverbal nominalizations (deverbal process and result nouns) have been selected from the above-mentioned corpus. Out of them, 802 examples (131 derivatives) belong to the category of deverbal process nouns, whilst the category of deverbal result nouns includes 163 examples (21 derivatives). It should be noted that the inventory of selected derivatives contained 152 deverbal nouns counted as types (the number counted as tokens (965 examples) is considerably higher, as the same derivatives are repeated several times in the corpus under investigation).

\subsection{The affixation of deverbal process nouns in Lithuanian and English}

In the Parallel Corpus, 131 deverbal process nouns in the Lithuanian language were found. These derivatives belong to ten derivational types ( 9 suffixes and 1 ending): -imas (72 derivatives, 268 examples), -ymas (23 derivatives, 179 examples), -tis ( 7 derivatives, 136 examples), -acija ( 7 derivatives, 12 examples), -yba (6 derivatives, 32 examples), - $a$ (6 derivatives, 37 examples), -slas (4 derivatives, 73 examples), -smas (2 derivatives, 34 examples), -estis (2 derivatives, 
6 examples), -ra (1 derivative, 23 examples), -alas (1 derivative, 2 examples). The examples of other productive derivative types (with suffixes -esys, -ulys, -sena) in the Parallel Corpus were not found.

As it was mentioned above, the biggest group of derivatives (72 cases) is composed of process nouns with the suffix -imas: in total, 268 Lithuanian sentences and their equivalents were analysed. A very large number of examples were found in the corpus with such derivatives as susirinkimas 'meeting', perdavimas 'transference', atlyginimas 'payment', and atgaminimas 'reproduction'. It should be noted that the aspect of polysemy (the concrete meanings of derivatives) was not analysed, therefore, the examples taken from the Parallel Corpus were not corrected or amended.

The analysis of empirical material proves that the derivatives with the suffix -imas and its allomorph -ymas in Lithuanian mostly have the equivalents of the derivatives with the suffix -ion/-sion/-tion/-ation in the English language. Furthermore, these suffixes are very productive both at the type and the token levels (e. g. atgaminimas - reproduction, atsistatydinimas - resignation, draudimas prohibition, paskelbimas - communication, iškraipymas - distortion, taikymas application, etc.). Consider the examples:
a. Kürinio
laikinas
work.GEN.SG.M
temporary.NOM.SG.M
b. Temporary Reproduction of a Work.

atgaminimas.

reproduction.NOM.SG.M

The equivalents of deverbal process nouns with the suffix -imas/-ymas in the Lithuanian language correspond to deverbal nouns with the suffix -ing in the English language (e.g. dainavimas - singing, deklamavimas - reciting, finansavimas - financing, grojimas - playing, padidinimas - increasing, perdirbimas - processing, pirkimas - buying, susirinkimas - meeting, padarymas making, pasirašymas - signing, skaitymas - reading, vaidinimas - acting, etc.). Consider the examples:
a. Valstybès
tikslinis
finansavimas $[.$.
state.GEN.SG.F
targeted.NOM.SG.M
financing.NOM.SG.M
b. The State targeted financing [..]

Also, quite often the derivatives with the suffix -imas/-ymas have the equivalents with the suffix -ment in English (e.g. apdorojimas - treatment, atsiradimas - commencement, gynimas - enforcement, reikalavimas - requirement, reklamavimas - advertisement, tobulinimas - improvement, etc.). For example:
a. Autoriu
teisiu
atsiradimas.
author.GEN.PL.M
right.GEN.PL.F
commencement.NOM.SG.M
b. Commencement of the Authors'Rights.

Furthermore, not so prolific are the derivatives with the suffix -imas/-ymas which have the equivalents of the derivatives with the suffix -ance/-ence (e.g. atlikimas - performance, paveldejimas - inheritance). Consider the examples:
a. Autoriu
turtiniu
teisiu
paveldejimas $[.$.
author.GEN.PL.M economic.GEN.PL.F right.GEN.PL.F inheritance.NOM.SG.M
b. Inheritance of Economic Rights of Authors [..] 
Some derivatives with the suffix -imas/-ymas in the Lithuanian language correlate with the derivatives with the suffixes -al and -age in the English language (e. g. pasiūlymas - proposal, tvirtinimas - approval, saugojimas - storage), as in:
a. Pasiūlymas
Vyriausybei.
proposal.NOM.SG.M
government.DAT.SG.F
b. Proposal to the Government.

Also, the derivatives with the suffix -imas/-ymas have the equivalents that belong to the type of zero derivation (conversion) in English (e. g. naudojimas use, suteikimas - transfer).

The analysis of deverbal process nouns in Lithuanian revealed that often the derivatives with the suffix -imas/-ymas have more than one equivalent in English (e.g. pažeidimas - infringement, violation; atlyginimas - remuneration, compensation, recovery). For example:
a. Autoriu
teisiu $[.$.
pažeidimas.
author.GEN.PL.M right.GEN.PL.F
infringement.NOM.SG.M

b. Infringement of [..] Sui Generis Rights.

c. Informacijos apie teisiu valdyma

information.GEN.SG.F about right.GEN.PL.F management.ACC.SG.M pažeidimas.

violation.NOM.SG.M

d. Violation of Rights - Management Information.

Some deverbal process nouns with the suffix -imas/-ymas in the Lithuanian language have the equivalents of derivatives with the suffixes -ion/-sion/ -tion/-ation (e.g. perdavimas - transmission, panaudojimas - exploitation, reproduction, pakeitimas - alteration), -ing (e. g. pakeitimas - altering, rodymas showing) as well as conversion (e.g. perdavimas - transfer, panaudojimas - use, pakeitimas - change, rodymas - display) in the English language. It should be noted that the suffix -imas/-ymas in Lithuanian and the suffix -ion/-sion/-tion/-ation in English are especially prolific in forming deverbal process nouns: 53 derivatives with the suffix -imas/-ymas have 58 English equivalents with the suffix -ion/-sion/ -tion/-ation in the corpus under investigation.

The deverbal process nouns with the suffix -tis have the equivalents with the suffixes -ion/-sion/-tion/-ation, -ment, -th in English (e.g. sudetis - composition, sutartis - agreement, mirtis - death, etc.). Due to the typological differences of both languages, the cases were found when deverbal process nouns with this suffix in Lithuanian have their equivalents as abstract or concrete nouns in English (e. g. paskirtis - purpose, paslaptis - secret, sutartis - contract, certificate). Some derivatives with the suffix -tis have more than one equivalent (derivatives and non-derivatives). For example, the equivalent for the derivative sutartis is mostly agreement (the derivative with the suffix -ment), but sometimes its equivalents are non-derivatives (e.g. contract, certificate). Consider:
a. Leidybos
sutartis
turi
büti $[.$.
publishing.GEN.SG.F
agreement.NOM.SG.F
has.PRS. 3
be.INF
b. A publishing agreement shall be [..] 

c. Bendrove,
gavusi $[.$.
sutarties $[.$.
company.NOM.SG.F
receive.PTCP.NOM.SG.F
certificate.GEN.SG.F
kopija [..]
copy.ACC.SG.F
d. The company, having received a copy of the certificate [..]

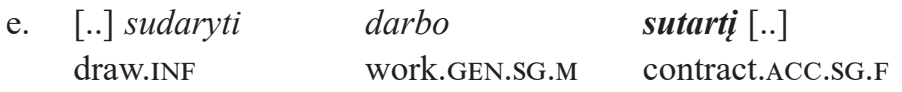
f. [..] to draw up a contract [..]

The derivatives paskirtis and kryptis with the suffix -tis have the equivalents of non-derivatives (e.g. purpose, trend, sphere), or they belong to the type of conversion (e.g. use):
a. Paramos
kaimo
plètrai
support.GEN.SG.F village.GEN.SG.M development.DAT.SG.F
kryptys.
trend.NOM.PL.F
b. Trends of support for rural development.

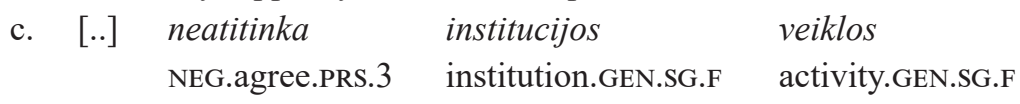

\section{krypties.}
sphere.GEN.SG.F
d. [..] are outside the sphere of competence of its institution.

The derivatives with the suffixes -slas (e.g. mokslas - science, pamokslas sermon, verslas - business), -yba (e.g. taryba - council, valdyba - board, prekyba - trade, mityba - nutrition), -smas (e.g. teismas - court), -alas (e.g. reikalas - affair) have the equivalents of non-derivatives in the English language. The same Lithuanian suffixes may have English equivalents, i. e. deverbal process nouns with the suffixes -ion/-sion/-tion/-ation (e.g. statyba - construction, veiksmas - action), -ment (e.g. neteisetas veiksmas - infringement), -estis (e.g. užmokestis - payment). Other cases, though not so prolific, are the derivatives with the suffixes -ra (e.g. pletra-development), -acija (e.g. adaptacija-adaptation, klasifikacija - classification, kompensacija - compensation). As it was already mentioned, due to typological differences of both languages, deverbal process nouns can be derived with endings in the Lithuanian language. For instance, with the ending -a: parama-support, nuožiūra-discretion.

The deverbal process nouns, such as gamyba, tikslas, veiksmas, mokestis, transliacija, apskaita, with the suffixes -yba, -slas, -smas, -estis, -acija and the ending - $a$ have more than one English equivalent, i. e. the derivatives with the suffixes -ion/-sion/-tion/-ation, -ment, -ing, -age as well as abstract nouns and conversion (e.g. gamyba - production, manufacture; tikslas - advantage, purpose, use, objective, goal; veiksmas - action, infringement, act; mokestis - payment, fee; transliacija - broadcasting, transmission; apskaita - accountancy, accounting, etc.). 
For example:
a. [..] fonogramu,
išleistu
komerciniais
phonogram.GEN.PL.F publish.PTCP.GEN.PL.F commercial.INS.PL.M tikslais $[.$.
purpose.INS.PL.M
b. [..] phonograms published for commercial advantage [..].
c. Šio
Istatymo
tikslas [..]
this.GEN.SG.M law.GEN.SG.M
purpose.NOM.SG.M
d. The purpose of this Law [..]

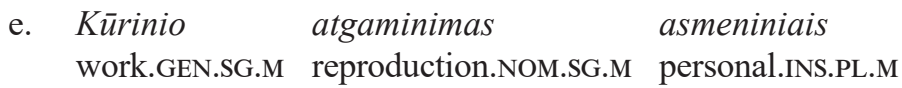
tikslais.
Work.GEN.SG.M reproduction.NOM.SG.M
Reproduction of Works for Personal Use.

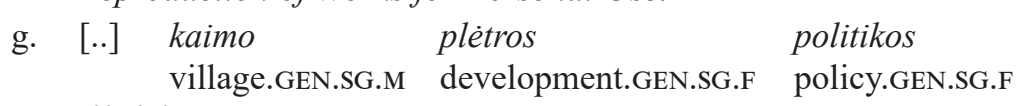
tikslai.
objective.NOM.PL.M
h. Objectives of the [..] Rural Development Policy.
i. [..] naudoti kitiems tikslams [..]
use.INF other.DAT.PL.M goal.DAT.PL.M
j. [..] to be used for goals other [..]

In conclusion, it should be noted that there are 30 derivatives that have more than one equivalent (derivative or non-derivative) in English found in the corpus under investigation.

\subsection{The affixation of deverbal result nouns in Lithuanian and English}

In the analysed corpus, 21 deverbal result nouns were found. These derivatives are formed with 7 suffixes (-inys, -muo, -snis, -mena, -stas, -ena, -liava) and 3 endings $(-a,-\dot{e},-(i) u s)$. Having analysed 163 examples in Lithuanian and their equivalents in English, it was noted that the derivational category of deverbal result nouns includes the nouns denoting either the end of the action or its result. The Lithuanian suffix -inys has the equivalents with the suffixes, such as -ion/sion/-tion/-ation (e.g. junginys - a combination, leidinys - a publication), -ment (e. g. teiginys - a statement), also the cases of zero derivation (conversion) (e.g. kürinys $-a$ work), or the equivalents of concrete nouns (e.g. turinys - contents, uždavinys - task). For example:
a. [..] asociaciju
uždaviniai
ir funkcijos. association.GEN.PL.F
task.NOM.PL.M
and
function.NOM.PL.F
b. Tasks and Functions of [..] Associations.

The derivative rinkinys with the suffix -inys has more than one equivalent in English: with the suffix -ion/-sion/-tion/-ation (e.g. compilation, collection) and zero derivation (e. g. set), or a concrete noun (e.g. entry):
a. [..] küriniu work.GEN.PL.M
rinkiniai
ar duomeny
rinkiniai $[.$.
collection.NOM.PL.M or
data.GEN.PL.M
collection.NOM.PL.M 
b. [..] collections of works or compilations of data [..]

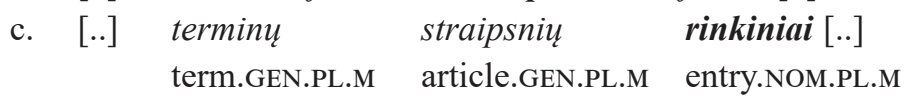

d. Entries of terms [..]

e. Terminu straipsniu

term.GEN.PL.M article.GEN.PL.M set.NOM.SG.M

f. "Set of term entries" [..]

The derivatives with the suffixes -muо (duomиo-data), -snis/-snys (veiksnys factor), -mena (žemès [ükio] naudmena - land), -stas (skliaustas - bracket), -ena (iškasena - resource), -liava (rinkliava - fee) in the English language have the equivalents denoting abstract or concrete nouns (i. e. non-derivatives). Also, deverbal result nouns in Lithuanian can be formed with the endings: -ius (skyrius chapter), -a (pažyma-certificate, paskola-loan). For example:
a. [..] pateikti reikalaujamus $[.$.
provide.INF require.PTCP.ACC.PL.M
duomenis.
data.ACC.PL.M
b. [..] provide the data required [..]

The deverbal result nouns with the suffix -snis have the equivalents of concrete nouns (e.g. skirsnis - section, chapter), and the derivatives with the suffix -muo have the equivalents of zero derivation (žymuo - label, mark). The derivative with the ending $-\dot{e}$ (priemone $\dot{e}$ ) has the equivalents that belong to the category of zero derivation (measure) and concrete noun (device).

Having analysed 152 derivatives (deverbal process nouns and deverbal result nouns) in the Lithuanian language and their equivalents in English, it may be stated that the deverbal noun suffixes -imas/-ymas in Lithuanian and -ion/-sion/ -tion/-ation in English are especially prolific in forming deverbal process nouns. The derivatives formed with different suffixes (deverbal process nouns: -tis, -acija, -yba, -slas, -smas, -estis, -ra, -alas; deverbal result nouns: -inys, -muo, -snis, -mena, -stas, -ena, -liava), and endings $(-a,-\dot{e},-i u s)$ in the Lithuanian language often have English equivalents with the suffix -ing, the derivatives with other suffixes (-ment, -ance/-ence, -al, -age, -ery, -th) are not so frequent. There are cases when the derivatives in Lithuanian have equivalents that are non-derivatives (conversion or concrete / abstract nouns) in the English language.

The analysis of the empirical material revealed that the derivatives in Lithuanian often have more than one equivalent in English: 30 deverbal process nouns (out of 131 derivatives) and 6 deverbal result nouns (out of 27 derivatives) have more than one equivalent in the English language.

\section{Conclusions}

In this paper, an attempt was made to describe and analyse the affixation of lexical deverbal nominalizations in typologically different languages Lithuanian and English. Although deverbal nominalizations in both the Lithuanian and English languages are divided into a range of semantic and derivational categories: process nominalizations, result nominalizations, agentive nominalizations, instrumental nominalizations, locative nominalizations, as well as nominalizations denoting 
the names of festivals and ceremonies, due to space limitations only deverbal process and result nominalizations were analysed in the present research.

The inventory of affixes forming deverbal nominalizations is significantly different. In Lithuanian, the deverbal nominalizations (deverbal process nouns and deverbal result nouns) may be formed with 132 suffixes and 5 endings, while in English the deverbal nominalizations are formed with 10 suffixes. Also, such deverbal nouns may be formed through conversion, which is not the case in Lithuanian.

In total, 802 examples of deverbal process nouns (131 derivatives) were selected from the Parallel Corpus: 447 sentences contain 95 derivatives with the most prolific suffix -imas/-ymas. These derivatives make 73 per cent of all deverbal process nouns, and the examples of their usage make 56 per cent of all examples. Also, 163 examples of deverbal result nouns (21 derivatives) were selected and analysed: 50 sentences contain 8 derivatives with the productive suffix -inys. These derivatives make 38 per cent of all deverbal process nouns, and the examples of their usage make 31 per cent of all examples.

While comparing the examples in Lithuanian and their equivalents in English, it was revealed that there is no direct correlation between Lithuanian and English suffixes: Lithuanian deverbal nouns have equivalents of countable and uncountable nouns in English (i.e. they are not nominalizations), especially in the case of deverbal result nouns. The equivalents in the English language mostly have the suffix -ion/-tion/-sion/-ation: they make 36 per cent of all derivatives, quite many derivatives have the suffix -ing. Moreover, in the Lithuanian language 23 per cent of all derivatives have more than one equivalent (derivative or non-derivative) in the English language. Also, the equivalents of some deverbal process nouns that have more concrete meaning and the majority of deverbal result nouns are non-derivatives, i. e. they are abstract or concrete nouns: out of 27 deverbal result nouns, 18 equivalents in English are non-derivatives and this makes 67 per cent of all equivalents.

To conclude, referring to existing theoretical models of derivational and inflectional morphology, the research demonstrates that a traditional long-standing typological distinction reflects formal, i.e. derivational distinctions in forming deverbal nominalizations through suffixes and endings. The approach to deverbal nominalizations that has been presented in this study encompasses only two types: deverbal process nouns and deverbal result nouns. Further research could involve a comparative study of deverbal agentive, instrumental, locative, etc. nouns within the theoretical framework which we have proposed in the present study.

\section{Abbreviations \\ 3 \\ third person \\ ACC accusative \\ DAT dative \\ F feminine \\ GEN genitive \\ INF infinitive}




$\begin{array}{ll}\text { INS } & \text { instrumental } \\ \text { M } & \text { masculine } \\ \text { NOM } & \text { nominative } \\ \text { PL } & \text { plural } \\ \text { PRS } & \text { present } \\ \text { PTCP } & \text { participle } \\ \text { SG } & \text { singular }\end{array}$

\section{Source}

Lygiagretusis tekstynas / Parallel Corpus. Available at: https://klc.vdu.lt/en/parallelcorpus/. Contributors: Čermak, František, Daudaravičius, Vidas, Skoumalova, Hana, Corness, Patrick.

\section{References}

1. Adams, Valerie. 1973. An introduction to Modern English word formation. London and New York: Routledge.

2. Ambrazas, Saulius. 1993. Daiktavardžiu darybos raida. Vilnius: Mokslo ir enciklopedijų leidykla.

3. Ambrazas, Vytautas (ed.). 1997. Lithuanian grammar. Lietuviu kalbos gramatika. Vilnius: Baltos lankos.

4. Ambrazas, Vytautas (ed.). 2008. Lietuviu kalbos enciklopedija. Vilnius: Mokslo ir enciklopedijų leidybos institutas.

5. Ambrazas, Vytautas (ed.). 2005. Dabartinès lietuviu kalbos gramatika. Vilnius: Mokslo ir enciklopedijų leidybos institutas.

6. Andersen, Øivin. 2007. Deverbal nouns, lexicalization, and syntactic change. Nordic Journal of Linguistics. 30(1), 55-86.

7. Banks, David. 2003. The evolution of grammatical metaphor in scientific writing. Grammatical metaphor. Views from systemic functional linguistics. SimonVandenbergen, Anne-Marie, Ravelli, Louise, Jane (eds.). Amsterdam: John Benjamins, 125-147.

8. Chomsky, Noam. 1970. Remarks on nominalization. Readings in transformational grammar. Jacobs, Roderick A., Rosenbaum, Peter S. (eds.). Waltham: Ginn and Company, 184-221.

9. Comrie, Bernard. 1976. The syntax of action nominals: a cross-language study. Lingua. 40, 177-201.

10. Comrie, Bernard, Thompson, Sandra A. 1985. Lexical nominalization. Language typology and syntactic description: grammatical categories and lexicon. 3. Shopen, Timothy (ed.). Cambridge: Cambridge University Press, 349-397.

11. Fillmore, Charles J. 1969. Towards a modern theory of case. Modern studies in English. Readings in transformational grammar. Reibel, David A., Shane, Sanford A. (eds.). New Jersey: Prentice-Hall, 361-375.

12. Gaivenis, Kazimieras, Keinys, Stasys. 1990. Kalbotyros terminų žodynas. Kaunas: Šviesa.

13. Givón, Talmy. 1984. Syntax. A Functional-Typological Introduction. 1. Amsterdam: John Benjamins. 
14. Halliday, Michael, Alexander, Kirkwood. 1985. An introduction to functional grammar. London: Arnold.

15. Heyvaert, Liesbet. 2003. A cognitive-functional approach to nominalization in English. Berlin / New York: Mouton de Gruyter.

16. Jackendoff, Ray. 1981. X syntax. A study of phrase structure. Cambridge: Massachusetts Institute of Technology Press.

17. Keinys, Stasys. 1999. Bendrinès lietuvių kalbos žodžių daryba. Šiauliai: Šiaulių universiteto leidykla.

18. Lakoff, George. 1970. Irregularity in syntax. New York: Holt, Rinehart \& Winston, Inc.

19. Kiparsky, Paul. 2017. Nominal verbs and transitive nouns: vindicating lexicalism. On looking into words (and beyond). Bowern, Claire, Horn, Laurence, Zanuttini, Raffaella (eds.). Berlin: Language Science Press, 311-346.

20. Koptjevskaja-Tamm, Maria. 2003. Action nominal constructions in the languages of Europe. Noun phrase structure in the languages of Europe. Plank, Frans (ed.). Berlin: de Gruyter Mouton, 723-759.

21. Mackenzie, J. Lachlan. 1998. Entity concepts. Morphology: a handbook of inflection and word formation. Berlin: Walter de Grayter.

22. McCawley, James, David. 1968. The role of semantics in grammar. Universals in linguistic theory. Bach, Emmon, Harms, Robert Thomas (eds.). New York: Holt Rinehart \&Winston, Inc. 125-169.

23. Marchand, Hans. 1969. The categories and types of present-day English wordformation. München: C.H. Beck'sche Verlansbuchendlung.

24. Pakerys, Jurgis. 2006. Veiksmo pavadinimo konstrukcija lietuvių kalbos gramatikoje. Daiktavardinio junginio tyrimai. Lietuviu kalbos gramatikos darbai. 4. Holvoet, Axel, Mikulskas, Rolandas (eds.). Vilnius: Lietuvių kalbos instituto leidykla, 121-149.

25. Paulauskienè, Aldona. 1994. Lietuviu kalbos morfologija. Vilnius: Mokslo ir enciklopedijų leidykla.

26. Paulauskienè, Aldona, Valeika, Laimutis. 1994. Modern Lithuanian. Vilnius: Žodynas.

27. Plag, Ingo. 2016. English. Word-formation - an international handbook of the languages of Europe. 4. Müller, Peter O., Ohnheiser, Ingeborg, Olsen, Susan, Rainer, Franz (eds.). Berlin: De Gruyter Mouton, 2411-2427.

28. Murmulaitytè, Daiva. 1997. Dabartinès lietuvių kalbos žodyno veiksmažodinių daiktavardžių semantinè ir statistinè analizė (priesagos -imas/-ymas ir galūnės - $a$ vediniai). Daktaro disertacija. Vilnius: Lietuvių kalbos institutas, Vytauto Didžiojo universitetas.

29. Quirk, Randolph, Greenbaum, Sidney, Leech, Geoffrey, Svartnik, Jan. 1985. A comprehensive grammar of the English language. London: Longman.

30. Ravelli, Louise, Jane. 1988. Grammatical metaphor: an initial analysis. Grammatical metaphor. Views from systemic functional linguistics. Simon-Vandenbergen, Anne-Marie, Ravelli, Louise Jane (eds.). Amsterdam: John Benjamins, 133-147.

31. Sušinskienè, Solveiga. 2010. Textual functions of nominalizations in English scientific discourse. Žmogus ir žodis. 11(3). Vilnius. Vilniaus Pedagoginio universiteto leidykla, 58-63.

32. Ulvydas, Kazys (ed.). 1965. Lietuviu kalbos gramatika. I. Vilnius: Mintis. 
33. Urbutis, Vincas. 2009. Žodžių darybos teorija. Vilnius: Mokslo ir enciklopedijų leidybos institutas.

34. Valeika, Laimutis, Sušinskienè, Solveiga. 2012. Aspect in English and Lithuanian. Šiauliai: Šiaulių universiteto leidykla.

35. Vaskelienè, Jolanta. 1998. Lietuviu kalbos darybiniai sinonimai (veiksmažodžiu abstraktai). Daktaro disertacija. Vilnius: Vilniaus universitetas.

36. Veselovska, Ludmila. 2018. Morphological taxonomy in the present-day generative framework: a case study of English and Czech nominalization. Topics in Linguistics. 19(2), 1-21.

37. Tumelis, Juozas (ed.). 2009. Visuotinè lietuviu enciklopedija. XVI. Vilnius: Mokslo ir enciklopediju leidybos institutas. Available at: http://www.vle.lt/

38. Zaika, Natalia. 2016. Lithuanian nominalizations and the case marking of their arguments. Argument realization in Baltic. Holvoet, Axel, Nau, Nicole (eds.). Amsterdam, Philadelphia: John Benjamin Publishing Company, 523-549.

\section{Kopsavilkums}

Lai gan lietuviešu un angḷu valodas ir indoeiropiešu valodu saimes valodas, šo valodu fleksīvā un derivatīvā morfologijijas sistēma atklāj tipoloǵiskas valodu atškirīỉbas. Rakstā tuvāk aplūkots nominalizācijas jēdziens un verbālā nominalizācija lietuviešu un angḷu valodā. Pētījumam izmantots „Paralēlo tekstu korpusa” materiāls: 802 verbu abstraktu un 163 derivātu, kas ir darbības rezultāta derivatīvās kategorijas, tulkojumi no lietuviešu valodas angḷu valodā (kopā 965 teikumi).

Morfologiskā izpratnē nominalizāciju var raksturot kā procesu, kura gaitā par substantīvu kḷūst citu vārdšķiru vārdi. Vispirms tas ir vārddarināšanas process, kurā substantīvs tiek darināts no verba, adjektīva vai no cita substantīva (lietuviešu valodā arī no citām vārdškiirām), parasti izmantojot dažādus sufiksus, lietuviešu valodā arī fleksijas. Ir divējāda nominalizācija - leksiskā un sintaktiskā. Leksiskās nominalizācijas rezultātā no verba vai nomena rodas verbāls vai nomināls substantīvs, bet sintaktiskajā nominalizācijā teikums kḷūst par nominālu frāzi.

Lai gan lietuviešu un angḷu valodas verbālā nominalizācija tiek iedalīta līdzīgās semantiskās un derivatīvās pamatkategorijās, lietuviešu valodas verbālās nominalizācijas derivācijas līdzekḷu un to ang̣̣u valodas ekvivalentu pētījums atklāj atšķirības. Lietuviešu valodā verbālās nominalizācijas - darbības abstrakcijas un darbības rezultāta nosaukumi - var tikt atvasināti ar 132 sufiksiem un 5 fleksijām, bet angḷ valodā - ar 10 sufiksiem un konversijas ceḷā. Empīriskā materiāla analīze liecina, ka lietuviešu valodā dominē verba abstrakcijas derivāti ar sufiksu -imas / -ymas (73 proc. no visiem analizētajiem abstrahējumiem), starp darbības rezultāta nosaukumiem visvairāk ir derivātu ar sufiksu -inys (38 proc. no visiem analizētajiem piemēriem). Angḷu ekvivalenti parasti ir ar sufiksiem -ion / -tion / -sion / -ation, samērā daudz ir arī derivātu ar -ing. Verbālā nominalizācija lietuviešu valodā nereti korelē ar abstrahējumiem un konkrētiem substantīviem (ne nominalizāciju) angḷu valodā. Turklāt 23 proc. lietuviešu valodas derivātu ang̣̣u valodā atbilst vairāki ekvivalenti (derivāti vai nederivāti).

Atslēgvārdi: nominalizācija; derivāts; sufikss; fleksija; verbālsubstantīvs; lietuviešu valoda; angḷ valoda. 